\title{
A Gap Analysis on Awareness and Utilization of Social Media Banking - The New Line of Self Service Banking
}

\section{G. Thamaraiselvi}

\begin{abstract}
Today the scenario has changed from geographically-based community to electronically-based one. For all kinds of banking transactions, the users of social media can be very well targeted. In Internet Banking, there are three basic kinds like informational level, communicative level and finally the transactional level. All the banks in India have already gone through the first two levels and all of them are in the transactional level as far as the Net Banking is concerned. This study stepped to know the gap between the awareness and utilisation of social media banking services. It is found that there is a wide gap between the awareness and utilisation of various services of Social Media Banking by the users.
\end{abstract}

Key words: Internet Banking, Social Media Banking, Awareness and Utilisation, Electronic Banking, Gap Analysis

\section{INTRODUCTION}

$\mathrm{W}$ ith top-line growth increasingly elusive, banks view self-service banking revenue drivers as the torch that lights their way for new possibilities. There was an increase in the usage of internet and banks commercialise this benefit by introducing Internet Banking. Similarly due to the telecommunication revolution, one can say that there is no single person without a mobile. And this benefit is also commercialised by banks through the introduction of Mobile Banking. The latest in this list is the commercialisation of the increase in the use of social media like Facebook, twitter and so on. Social media channel can be used for banking and it opens up new revenue line for banks.

Today the scenario has changed from geographically-based community to electronically- based one. For all kinds of banking transactions, the users of social media can be very well targeted. In Internet Banking, there are three basic kinds like informational level, communicative level and finally the transactional level. All the banks in India have already gone through the first two levels and all of them are in the transactional level as far as the Net Banking is concerned.

Similarly, these levels can be applied to the social media banking. In India, ICICI Bank is the only bank and first bank which enabled its banking services accessible through the social media of Facebook. It is at the transactional level of social media banking. Axis Bank has opened its account in Facebook thereby launching its social media banking at informational level. The other banks are HDFC Bank, Kotak

Revised Manuscript Received on December 09, 2019.

Ms. G. Thamaraiselvi , Assistant Professor, Department of Commerce, Kalasalingam Academy of Research and Education, Krishnankoil. TamilaNadu, India Email: thamaraiselvi@klu.ac.in
Mahindra Bank, Yes Bank, Development Credit Bank, Federal Bank, South Indian Bank, InduInd Bank, IDBI Bank, Citibank, Standard Chartered Bank and American Express Bank. ICICI Bank allows its customers to access its banking services from facebook itself by downloading its application (app) in the customer's facebook account by using the customer's debit card and its PIN (Personal Identification Number). Today, there are millions of people using facebook in India. This facebook banking of ICICI Bank enables the young consumers who spend a lot of time in facebook to carry out the banking activities without having to leave the social media website.

This social banking service of ICICI Bank allows paying money to the friends of the customers without the need to specify their account details like account number, bank name, IFS (Indian Financial System) code etc. Instead the customer can just mention the transferee's e-mail id and mobile phone number. On transacting this, an electronic coupon is generated along with a pass code. The coupon details along with the pass code are sent to the transferee's mobile number or e- mail ID or facebook depending on the friend's contact medium as set by the customer at the time of generating the coupon. Also another pass code will be generated on the customer's mobile number which is also to be sent to the transferee. The friend can redeem the coupon at the bank's website in facebook and inputing his account details.

The split and share facility offered in the facebook banking of the Bank allows a customer to manage, track, share and settle group expenses of the activity like group picnic, movies, outing etc. The other services available on facebook banking are recharging for mobiles, booking movie tickets, viewing all ICICI Bank relationships, fund transfers and the like. The full-fledged services of ICICI Bank via the facebook has attracted the customers to the greatest extent in such a way that this Bank tops the list in the number of fans in a survey conducted by Unmetric in the three months period of January to March of 2013 registering a growth of 75 per cent when compared to the previous year.

\section{Safety in Social Media Banking}

Internet is prone to many attacks. And social media is also subject to cyber crimes. Obviously, it cannot be outside the purview of security threats

endangering the victim's credential information. Even when the banks, particularly ICICI Bank in facebook banking claims that it offers safe and secure banking

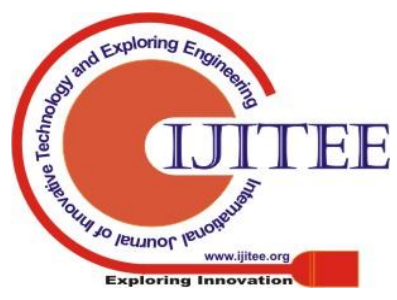


platform via facebook, this feature also opens up a "safe place" for online criminals to carry out their surreptitious operations. India has more than 82 million facebook users and also there is a good chance for those customers of ICICI Bank to use facebook. If they start using the Bank's facebook banking feature, it would really intensify the cyber crimes endangering security threats in the banking operations. So the banks in social media platform have to ensure 100 per cent security just like in other modes of Electronic Banking.

In the society banking in social media is new, we can reason that it is here to stay. In our everyday life social media gradually found its way into various aspects by replacing our traditional media. It became very popular among the people. Social media is not only a platform in where business people can communicate with their customers but also it provides a path to create stable and benefitable relationship with customers by making different types of transactions simple. The bakers aware of the power of social media because it offers the customers a voice. Comparing traditional media, social media helps the bankers to connect and reach their customers far more from all over the world.

\section{Banks in Social Media}

\begin{tabular}{|c|c|c|}
\hline Banks & No of Channels & Social Grades \\
\hline HDFC BANK & 8 & 3.06 \\
\hline ICICI BANK & 8 & 2.81 \\
\hline AXIS BANK & 5 & 2.28 \\
\hline CITI BANK & 5 & 2.02 \\
\hline YES BANK & 6 & 1.97 \\
\hline KOTAK MAHINDRA & 5 & 1.62 \\
\hline STANDARD CHARETERED & 4 & 1.8 \\
\hline INDUS IND BANK & 4 & 1.24 \\
\hline ING VYSYA BANK & 3 & 0.79 \\
\hline SOUTH INDIAN BANK & 3 & 0.72 \\
\hline KARNATAKA BANK & 3 & 0.57 \\
\hline BANK OF PUNJAB & 2 & 0.36 \\
\hline
\end{tabular}

\section{REVIEW OF LITERATURE}

Dhanabhakyam and Malarvizhi (2012) studied the awareness of the Kisan Credit Card (KCC) holders and their attitude towards the cards and reviewed their extent of utilisation using the Chi-Square analysis. It was found from their study that KCC was one of the most innovative, widely accepted banking products used among the agriculturalists in the study area. So the awareness level of the KCC instrument was higher among the customers in the area and they were utilising this loan facility efficiently.

Sudhagar (2012) tried to identify the awareness of the Credit Cards and assessed the eligible credit limits and the limits availed by the customers and studied the extent of usage of the Credit Cards. He pointed out that many customers surrender their Credit Cards and the banks too to have stopped further issuing Credit Cards. He finally concluded that as people were yet to realise the complete potential of Credit Card, its market was falling down.

Govindarajan, Anand Vijay and Balachandran (2012) analysed the awareness and utilisation regarding the usage of

Credit Cards using the Analysis of Variance tool. They concluded that the customers were aware of the security check and they did not care about the reward points given by the Credit Card companies. Further the debit card holders reported positively that they would start using the Credit Cards, in spite of their fearness that the Credit Cards might increase their spending habit if the bankers approach them.

\section{THE SCOPE OF THE STUDY}

This study covered to Dindigul town. The major scope is to study the gap between awareness and utilisation of the respondents in Social Media Banking. It consists of both the non-financial and financial services in Social Media Banking

\section{OBJECTIVES OF THE STUDY}

The following are the objectives of the present study:

i) To study gap between awareness and utilisation of new line of self service banking - social media banking.

\section{RESEARCH METHODOLOGY}

\section{Sampling Deign}

The researcher adopted the quota sampling method for collecting the data. Large numbers of people are using the Social media banking services. As the population is large and unknown, the researcher has chosen the non-random sampling method. The researcher has taken 100 as the sample size. There are different categories of people who are availing the services of social media banking. Among them, the researcher has chosen 20 respondents each from categories of students, government employees, private employees, business people and professional people. In Table 5.1 the demographic characters of the respondents such as Age, Gender, Marital Status, Education, Family Monthly Income and Dwelling Place are presented.

Table 5.1 Demographic Characters

\begin{tabular}{|l|l|l|l|}
\hline \multicolumn{2}{|l|}{ Particulars } & Total Users \\
\cline { 3 - 4 } & Frequency & Percentage \\
\hline Age & $\begin{array}{l}\text { Below 25 } \\
\text { years }\end{array}$ & 28 & 28 \\
& $\begin{array}{l}25 \text { to } 40 \\
\text { years }\end{array}$ & 45 & 45 \\
\hline & $\begin{array}{l}\text { Above 40 } \\
\text { years }\end{array}$ & 27 & 27 \\
\hline Gender & Total & $\mathbf{1 0 0}$ & $\mathbf{1 0 0}$ \\
\hline \multirow{2}{*}{$\begin{array}{l}\text { Males } \\
\text { Status }\end{array}$} & Females & 66 & 66 \\
\hline & Total & $\mathbf{1 0 0}$ & 34 \\
\hline & Married & 66 & $\mathbf{1 0 0}$ \\
\hline & Unmarried & 34 & 66 \\
\hline Education & Total & $\mathbf{1 0 0}$ & $\mathbf{1 0 0}$ \\
\hline
\end{tabular}




\begin{tabular}{|c|l|l|l|}
\hline & UG & 43 & 43 \\
\hline & PG & 33 & 33 \\
\hline & Diploma & 5 & 5 \\
\hline $\begin{array}{c}\text { Family } \\
\text { Monthly } \\
\text { Income }\end{array}$ & $\begin{array}{l}\text { Total } \\
\text { Rs.20,000 }\end{array}$ & $\mathbf{1 0 0}$ & $\mathbf{1 0 0}$ \\
\hline & $\begin{array}{l}\text { Rs.20,000 } \\
\text { to Rs.50,000 }\end{array}$ & 33 & 53 \\
\hline & $\begin{array}{l}\text { Above } \\
\text { Rs.50,000 }\end{array}$ & 14 & 33 \\
\hline $\begin{array}{l}\text { Total } \\
\text { Place }\end{array}$ & Rural & $\mathbf{1 0 0}$ & 14 \\
\hline & Urban & 53 & 47 \\
\hline & Total & $\mathbf{1 0 0}$ & $\mathbf{1 0 0}$ \\
\hline
\end{tabular}

the same time it is observed that quite a number of customers are not aware of various facilities provided by the bankers. It is proper to evaluate the gap between the awareness and utilisation with the help of Gap Analysis developed by Parasuraman. A 3 point scale is constructed and used for analysing the gap between the awareness and utilisation of various services of Internet Banking, Mobile Banking and ATMs. It is constructed as follows:

\begin{tabular}{|l|l|l|l|}
\hline & 1 & 2 & 3 \\
\hline Awareness of & Not & Partially & Fully \\
Services & Aware & Aware & Aware \\
\hline Utilisation of & Not & Rarely & Frequently \\
Services & Using & Using & Using \\
\hline
\end{tabular}

The following Table 6.1 provides a Gap Analysis between the awareness and utilisation of various services that are provided to the Internet Banking customers.

Table 6.1 Awareness and Utilisation of Various Services

Source: Primary Data in Social Media Banking

It can be divulged from the above Table 5.1 that out of 100 respondents, 45 ( 45 per cent) respondents are in the age group of 25 to 40 years. 66 respondents ( 66 per cent) are males and 66 (66 per cent) respondents are married. Further, 43 (43 per cent) respondents are under graduates followed by 33 (33 per cent) post graduate respondents. 53 (53 per cent) respondents reported that their family monthly income level is below 20,000 and 53 (53 per cent) respondents is dwelling in urban areas.

It is observed that there is a greater proclivity towards the use of various Electronic Banking services among middle aged people than the other age groups. Further males are in majority and the females are just now emerging as Social Media Banking users. Most of the respondents are graduates and they have no fear or hesitation in using the new delivery channels of the banks to the maximum potential. There is also a greater inclination towards Social Media Banking services among respondents who dwell at town side and having a family monthly income of below 20,000. It is observed that the tendency to use Social Media Banking is highly prevalent among the people living in urban areas compared to the rural areas. For the inclusive growth, the Government is also making every effort to bring as many people possible in the normal banking channel.

\section{DATA INTERPRETATION}

This study has been carried out on customers' satisfaction towards shop at home. Questionnaire entails the questions are related to level of usage of online websites, products preferred to buy from online and customers' satisfaction level towards their shopping In questionnaire consists the options are frequently using, rarely using and never used and also Highly Satisfied, Satisfied, Neutral, Dissatisfied and Highly Dissatisfied.

\section{Awareness and Utilisation of Various Services in Social Media Banking}

In the analysis, it is found that many respondents are not using various services offered by the Net Banking platform and at 


\begin{tabular}{|c|c|c|c|}
\hline $\begin{array}{l}\text { Expected } \\
\text { Score }(100 \times 3)\end{array}$ & & & \\
\hline $\begin{array}{l}\text { Fund Transfer } \\
- \text { Within Bank } \\
\end{array}$ & 300 & 108 & 192 \\
\hline $\begin{array}{l}\text { Fund Transfer } \\
\text { - Other bank }\end{array}$ & 300 & 201 & 99 \\
\hline $\begin{array}{l}\text { Utility } \\
\text { Payments }\end{array}$ & 300 & 219 & 81 \\
\hline Tax Payments & 300 & 39 & 261 \\
\hline $\begin{array}{l}\text { NEFT } \\
\text { Settlement }\end{array}$ & 300 & 135 & 165 \\
\hline $\begin{array}{l}\text { RTGS } \\
\text { Settlement }\end{array}$ & 300 & 99 & 201 \\
\hline $\begin{array}{l}\text { Credit card } \\
\text { payment }\end{array}$ & 300 & 99 & 201 \\
\hline Demat facility & 300 & 36 & 264 \\
\hline $\begin{array}{l}\text { Shopping using } \\
\text { Social } \\
\text { media banking }\end{array}$ & 300 & 156 & 144 \\
\hline $\begin{array}{l}\text { Opening term } \\
\text { deposits }\end{array}$ & 300 & 30 & 270 \\
\hline $\begin{array}{l}\text { Stop cheque } \\
\text { payment }\end{array}$ & 300 & 45 & 255 \\
\hline $\begin{array}{l}\text { Donations and } \\
\text { Charity payments }\end{array}$ & 300 & 39 & 261 \\
\hline Total & 3600 & 1206 & 2394 \\
\hline
\end{tabular}

Source: Primary Data

\subsection{Results and Discussion of Findings}

Awareness Maximum Score for item is 3. There were 100 respondents. Total awareness score would be $300(100 \times 3)$. Utilisation Maximum Score for item may differ between 1-3. Total Utilisation Score would range according to item score of 100 respondents Gap would be the difference between Total Awareness Score and Total Utilisation Score. Average Construct Score would be the Total Gap Score is divided by number of each construct. So they are: Non-Financial Services $=2238 / 12=186.5$ and Financial Services = $2394 / 12=199.5$.

Table 6.2

\begin{tabular}{|l|c|c|c|}
\hline SERVQUAL & $\begin{array}{l}\text { Unweighted } \\
\text { SERVQUAL } \\
\text { Score }\end{array}$ & $\begin{array}{l}\text { Score of } \\
\text { Importance }\end{array}$ & $\begin{array}{l}\text { Weighted } \\
\text { Score }\end{array}$ \\
\hline $\begin{array}{l}\text { Non- } \\
\text { Financial } \\
\text { Services }\end{array}$ & 186.5 & 10 & 1865 \\
\hline $\begin{array}{l}\text { Financial } \\
\text { Services }\end{array}$ & 199.5 & 15 & 2992.5 \\
\hline
\end{tabular}

\section{Source: Primary Data}

\subsection{Findings}

There is a 3600 score regarding the awareness of the respondents in Non-financial services and the score for utilisation of the respondents with regard to Non-financial services is 1362 . There is a gap of 2238 score between the awareness and utilization of the respondents with regard to non-financial services of Social Media Banking.

With regard to the awareness score of financial services of Social Media Banking is 3600 and the score of utilisation of financial services in Social Media Banking is 1206. So there

is a gap of 2394 score between the awareness and utilisation of financial services of the respondents in Social Media Banking.

\section{CONCLUSION}

It is divulged from the study there is a wide gap between the awareness and utilisation of various services of Social Media Banking by the users. Only the knowledge of various services warrants the fullest utilisation of services to the maximum potential. So both the banks and customers have respective roles in increasing the level of awareness about the various services. Customers are hesitant to change. But they have to realise that they cannot avoid the new innovations replacing the traditional ones. The concept of Social Media Banking is not entirely Virtual Banking, but the co-existence of both Traditional and Virtual Banking. It is the choice of the customers to use the desired one. But the usage of Virtual Banking and the knowledge of how far it is better than the Traditional Banking have to be realised in the coming future. The usage of such electronic services will help in reducing the usage of physical currency. This will go a long way in helping the economy in numerous ways like reducing the printing cost of currency, less possibility of counterfeit notes and it is environmental friendly.

So it can be concluded that the utilisation of the non-financial services and financial services of Social Media Banking is not upto the level of awareness towards them. So the banks have to draw a strategy in making the respondents for utilising the non-financial services and financial services through Social Media Banking.

\section{REFERENCES}

1. G Carman, J.M. (1990), “Consumer perceptions of service quality: An assessment of the SERVQUAL dimensions", journal of Retailing, Vol.66 No.1, pp.33-55.

2. Cronin, J.J. and Taylor, S.A. (1992), "Measuring Service Quality: A Reexamination and Extension", journal of Marketing, Vol. 56, No. 3, pp. 55-68.

3. Rani Malika (2012), "A Study on the Customer Perception towards E-Banking in Ferozepur District", International Journal of Multidisciplinary Research, Volume 2, Issue 1, January, 2012.

4. Sudhagar (2012), "A Study on Perception and Awareness on Credit Cards among Bank Customers in Krishnagiri District”, IOSR Journal of Business and Management, Vol. 2, No. 3, pp. 14-23, July-Aug 2012.

5. Mahmood Zaigham (2009), "Attitudes towards the Use of E-Banking: Result of a Pilot Survey", Communications of the IBIMA, Volume 8, 2009 ISSN: 1943- 7765.

6. Gronroos, C. (1984), "A ServiceQuality Model and its Marketing Implications", European Journal of Marketing, Vol. 18, Iss. 4, pp 36-44.

\section{AUTHORS PROFILE}

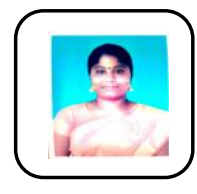

Mrs. G. Thamaraiselvi has been rendering her services as an Assistant Professor of Commerce, Kalasalingam Academy of Research and Education, krishnankoil, She published three papers in UGC listed journal and also three papers is ISBN. She acting as a lifetime member of various professional bodies like TERA,SSHRA, IEDRC and Association of North America Higher Education International. She presented many research papers in various seminar and conferences conducted national and international level. 